\title{
A COMPARATIVE STUDY OF ONDANSETRON AND PALONOSETRON AS ANTIEMETICS FOR PREVENTION OF POSTOPERATIVE NAUSEA AND VOMITING IN PATIENTS UNDERGOING LAPAROSCOPIC SURGERIES
}

\author{
Sarvesh N. K1, Shivakumar P. S2 \\ 1 Assistant Professor, Department of Anaesthesiology, DM Wayanad Institute of Medical Sciences, Wayanad. \\ ${ }_{2}^{2}$ Senior Resident, Department of Anaesthesiology, MVJ Medical College and Research Centre, Bangalore.
}

\section{ABSTRACT}

\section{BACKGROUND AND OBJECTIVES}

Nausea and vomiting have been associated for many years with the use of anaesthetic techniques for surgical procedure. Objective of the present study is to compare the efficacy of Palonosetron and Ondansetron for prevention of post-operative nausea and vomiting in patients undergoing laparoscopic abdominal surgeries under general anaesthesia.

\section{METHODOLOGY}

This randomized double blind prospective study was conducted during the period of 01-03-2013 to 31-08-2013 in Department of Anaesthesiology, Narayana Hrudayalaya Hospital, Bangalore. After institutional approval and with informed consent, 248 patients of ASA grades 1 and 2 between age groups of 18-55 years, posted for elective laparoscopic abdominal surgeries under GA were randomly selected and allocated into two groups of 124 each. Group 0 received Ondansetron 8 mg IV and group P received Palonosetron $0.075 \mathrm{mg}$ IV at the time of induction. Anaesthetic procedure was standardized and was common to all the patients. Postoperatively, the episodes of nausea, retching, vomiting and the need for rescue anti-emetics and side effects were assessed postoperatively for 24 hours at intervals of 0-4 hours, 4-8 hours, 8-12 hours and 12-24 hours. If there were two or more episodes of PONV during first 24 hours, rescue antiemetic metoclopramide $10 \mathrm{mg}$ IV was given. Kruskal-Wallis chi-square test was used to test the significance of difference between quantitative variables and Yate's chi square test for qualitative variables. A 'p' value less than 0.05 is taken to denote significant relationship.

\section{RESULTS}

The incidence of nausea, vomiting and use of rescue antiemetic was significantly less in Palonosetron group (8.9\%, 4\%, 2.4\%) as compared to Ondansetron group $(26.6 \%, 21.8 \%, 10.5 \%)$. The incidence of PONV was significantly less in Palonosetron group (13.7\%) as compared to Ondansetron group (33.9\%). The results were clinically and statistically significant.

\section{CONCLUSION}

Incidence of PONV and use of rescue anti-emetics is less in patients who had received IV Palonosetron in comparison to those who had received IV Ondansetron in patients undergoing laparoscopic abdominal surgeries under GA. From the study, we conclude that Palonosetron at a dose of $0.075 \mathrm{mg}$ is safe, well tolerated and proved more effective than Ondansetron $8 \mathrm{mg}$ in prevention of PONV.

\section{KEYWORDS}

Ondansetron; Palonosetron; General Anaesthesia (GA); Intravenous (IV); Postoperative Nausea and Vomiting (PONV); Nausea; Retching; Vomiting, Rescue; Anti-Emetics.

HOW TO CITE THIS ARTICLE: Sarvesh NK, Shivakumar PS. A comparative study of ondansetron and palonosetron as antiemetics for prevention of postoperative nausea and vomiting in patients undergoing laparoscopic surgeries. J. Evolution Med. Dent. Sci. 2016;5(40):2430-2435, DOI: 10.14260/jemds/2016/566

\section{INTRODUCTION}

Postoperative Nausea and Vomiting (PONV) are distressing symptoms that commonly occur after laparoscopic surgery performed under general anaesthesia. Overall incidence is $30 \%$, but in certain high risk patients it can be as high as $70 \% .1$ Laparoscopic surgeries are done very commonly nowadays in every parts of the world. They have many advantages compared to an open procedure like less surgical trauma, less intraoperative and postoperative pain, early discharge and above all the cosmetic benefit. Postoperative recovery is usually very rapid. PONV can be particularly

Financial or Other, Competing Interest: None.

Submission 04-04-2016, Peer Review 29-04-2016,

Acceptance 05-05-2016, Published 18-05-2016.

Corresponding Author:

Dr. Sarvesh N. K,

\#1424, 5th Stage, $1^{\text {st }}$ Phase, $6^{\text {th }}$ Cross,

BEML Layout, Rajarajeswari Nagar,

Bangalore-560098.

E-mail: drsarveshnk@yahoo.com

DOI: $10.14260 /$ jemds $/ 2016 / 566$ troublesome after laparoscopic surgeries.

Vomiting may cause dehydration, electrolyte imbalance and disruption of surgical repair and increase the perception of pain. ${ }^{2}$

Ondansetron is a selective 5-hydroxytryptamine receptor antagonist, which possesses property of superior antiemetic. This has been now used widely for the treatment of postoperative nausea and vomiting.

Palonosetron is a 5-HT3 receptor antagonist used for preventing chemotherapy induced nausea and vomiting. This unique 5-HT3 receptor antagonist has a greater binding affinity and longer half-life than older 5-HT3 antagonists like Ondansetron. Recent receptor binding studies suggest that Palonosetron is further differentiated from other 5-HT3 by interacting with 5-HT3 receptors in an allosteric, positively cooperative manner at sites different from those that bind with Ondansetron. ${ }^{3}$ In addition, this sort of receptor interaction may be associated with long lasting effects on receptor ligand binding and functional responses to serotonin. 4 
The purpose of this study is to compare the antiemetic efficacy of Ondansetron and Palonosetron to prevent postoperative nausea and vomiting in patients undergoing laparoscopic surgeries.

\section{AIMS AND OBJECTIVES}

To study the effect of single dose Ondansetron $8 \mathrm{mg}$ for the prevention of postoperative nausea and vomiting in patients undergoing laparoscopic surgeries.

To study the effect of single dose Palonosetron $0.075 \mathrm{mg}$ for the prevention of postoperative nausea and vomiting in patients undergoing laparoscopic surgeries.

To compare the efficacy between Ondansetron $8 \mathrm{mg}$ and Palonosetron $0.075 \mathrm{mg}$ as anti-emetics for the prevention of postoperative nausea and vomiting in patients undergoing laparoscopic surgeries.

\section{MATERIALS AND METHODS}

After obtaining written informed consent, two hundred and forty eight (248) patients were selected and allocated a serial number from 1 to 248 . By using a computer generated random number list, the participants were allocated to either group ' $O$ ' or ' $\mathrm{P}$ ' each containing 124 . The study was a prospective double blind randomized study. It was conducted at Narayana Hrudayalaya Hospital during the period from 01-03-2013 to 31-08-2013.

Group 0: Patients received Ondansetron $8 \mathrm{mg}$ IV at the time of induction.

Group P: Patients received Palonosetron $0.075 \mathrm{mg}$ IV at the time of induction.

\section{Inclusion Criteria}

- Patients aged 18-55 years.

- Either sex.

- ASA I-II.

- Patients posted for elective laparoscopic surgeries.

\section{Exclusion Criteria}

- Patients with previous history of postoperative nausea and vomiting.

- History of motion sickness.

- History of gastroesophageal reflux disease.

- Patient who has taken any antiemetic within 3 days of surgery.

- Patients weighing $>75 \mathrm{~kg}$.

- Pregnant females.

Sample Size is Calculated using the following Formula

- $\mathrm{n}=\mathrm{t}^{2} \mathrm{p}(1-\mathrm{p}) / \mathrm{m}^{2}$.

- $\mathrm{n}=$ required sample size.

- $\mathrm{t}=$ confidence level at 95\% (standard value of 1.96 ).

- $\mathrm{p}=$ estimated prevalence of PONV among high risk patients $=80 \%=0.80$.

- $\mathrm{m}=$ margin of error at $5 \%$ (standard value of 0.05 ) $=0.05$.

- Sample size $=\{1.962 \times 0.80(1-0.80)\} / 0.052$.

$=246.36$ rounded to 248 for the convenience of dividing into 2 equal groups.

During the study period (1-03-2013 to 31-08-2013) of 6 months, four hundred eligible cases were expected to attend this hospital, out of which cases satisfying the inclusion criterion and willing to participate in the study would be still less. Hence, all cases satisfying the inclusion criterion and willing to participate in the study were continuously included in the study till the required sample size was achieved.

\section{METHOD}

Pre-anaesthetic review of the patients was done a day before the surgery.

\section{Preoperative Investigations done Include:}

- Hb.

- Total count, differential count.

- Blood urea.

- Serum creatinine.

- Serum electrolytes.

- ECG $>40$ years.

The patients were advised to be nil by mouth after 23:00 hrs. They were administered tablet diazepam $(0.2 \mathrm{mg} / \mathrm{kg})$ and tablet Pantoprazole $40 \mathrm{mg}$ in the night and two hours before shifting the patient to operation theatre with sips of water.

On arrival in the operation theatre, an intravenous line was secured and maintenance fluid started. ASA standard monitors were connected. The patient was pre-oxygenated for 3 minutes and induced with propofol ( $2 \mathrm{mg} / \mathrm{kg}$ ), fentanyl ( 2 $\mathrm{ug} / \mathrm{kg})$, paralysed with vecuronium $(0.1 \mathrm{mg} / \mathrm{kg})$ IV and the patient was intubated with appropriate size endotracheal tube.

At induction, Group 0 received $8 \mathrm{mg}$ of Ondansetron and Group P will receive $0.075 \mathrm{mg}$ of Palonosetron diluted with NS to $4 \mathrm{~mL}$ intravenously; the administer being blinded to the drug given.

Anaesthesia was maintained with isoflurane, air and oxygen to a MAC of 1 . Vecuronium $(0.02 \mathrm{mg} / \mathrm{kg})$ and fentanyl $(1 \mathrm{ug} / \mathrm{kg}$ ) were administered when needed.

The patients were mechanically ventilated to keep $\mathrm{EtCO}_{2}$ between $35-40 \mathrm{mmHg}$. A nasogastric tube was inserted to empty the contents of stomach. For laparoscopic surgical procedure, peritoneal cavity was insufflated with carbon dioxide to keep intra-abdominal pressure $<14 \mathrm{mmHg}$. At the end of surgical procedure, residual neuromuscular block was adequately reversed using intravenous glycopyrrolate $[0.01$ $\mathrm{mg} / \mathrm{kg})$ and neostigmine $(0.05 \mathrm{mg} / \mathrm{kg})$ and subsequently extubated. Before tracheal extubation, the nasogastric tube was suctioned and removed. Adequate postoperative analgesia cover was given. All patients were observed postoperatively by resident doctors who were unaware of the study drug. Patients were transferred to post-anaesthesia care unit and blood pressure, heart rate and oxygen saturation monitored.

Incidence of nausea, retching and vomiting and the side effects was assessed postoperatively for 24 hours.

\section{The above Findings Were Recorded at the following Intervals}

- 0-4 hours, 4-8 hours, 8-12 hours and 12-24 hours in the postoperative period.

- If there were two or more episodes of PONV during first 24 hours, rescue antiemetic metoclopramide $10 \mathrm{mg}$ IV was given. If metoclopramide treatment was ineffective, dexamethasone $4 \mathrm{mg}$ IV was given.

\section{Statistical Tools}

The information collected regarding all the selected cases were recorded in a Master Chart. Data analysis was done with the help of computer using Epidemiological Information 
Package (EPI 2010) developed by Centre for Disease Control, Atlanta.

Using this software range, frequencies, percentages, means, standard deviations, chi square and ' $p$ ' values were calculated. Kruskal-Wallis chi-square test was used to test the significance of difference between quantitative variables and Yate's chi square test for qualitative variables. A ' $p$ ' value less than 0.05 is taken to denote significant relationship.

\section{RESULTS}

Group 0: Patients given Ondansetron.

Group P: Patients given Palonosetron.

\begin{tabular}{|c|c|c|c|}
\hline $\begin{array}{c}\text { Demographic } \\
\text { Profile }\end{array}$ & $\begin{array}{c}\text { Group 0 } \\
\text { Mean/SD }\end{array}$ & $\begin{array}{c}\text { Group P } \\
\text { Mean/SD }\end{array}$ & 'p' \\
\hline Age in years & $33.3 / 11.4$ & $36.3 / 11.1$ & 0.0622 \\
\hline Sex M/F & $56 / 68$ & $66 / 58$ & 0.253 \\
\hline Weight in kgs & $58.4 / 9.1$ & $58.6 / 9.7$ & 0.8288 \\
\hline $\begin{array}{c}\text { Duration in } \\
\text { minutes }\end{array}$ & $93.5 / 28.3$ & $91.2 / 18.7$ & 0.5081 \\
\hline
\end{tabular}

Table A: Comparison of Demographic Profile between Two Groups

\section{B: Efficacy of the two Drugs}

\begin{tabular}{|c|c|c|c|c|}
\hline \multirow{2}{*}{ Group } & \multicolumn{4}{|c|}{ No. of Cases with Nausea at } \\
\cline { 2 - 5 } & $\mathbf{0 - 4}$ hours & $\mathbf{4 - 8}$ hours & $\begin{array}{c}\mathbf{8 - 1 2} \\
\text { hours }\end{array}$ & $\begin{array}{c}\mathbf{1 2 - 2 4} \\
\text { hours }\end{array}$ \\
\hline Group 0 & 16 & 14 & 5 & 5 \\
\hline Group P & 5 & 2 & 2 & 2 \\
\hline 'p' & $\begin{array}{c}0.0226 \\
\text { Significant }\end{array}$ & $\begin{array}{c}0.0045 \\
\text { Significant }\end{array}$ & 0.2232 & 0.2232 \\
\hline \multicolumn{5}{|c|}{ Table B1: Incidence of Nausea } \\
\hline
\end{tabular}

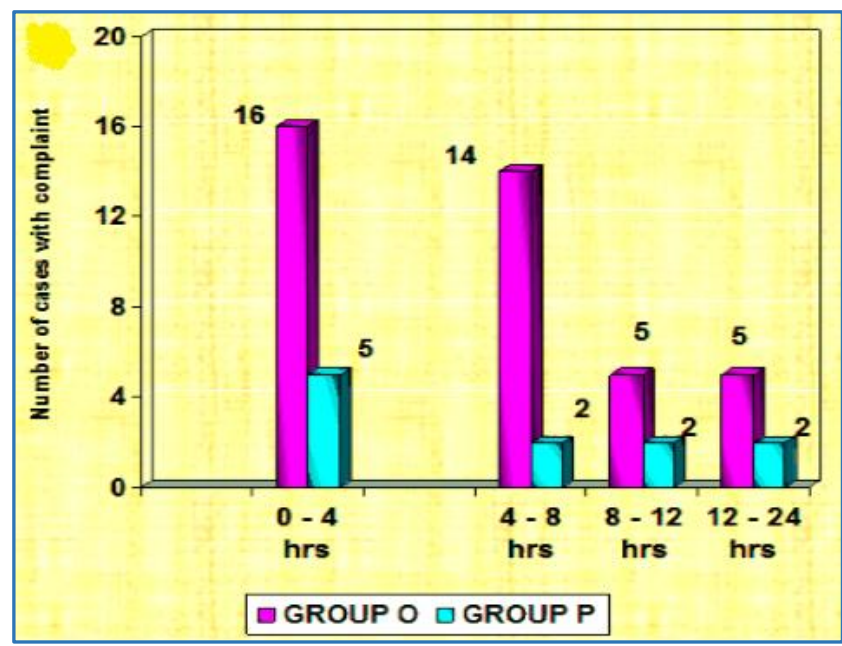

Fig. B1: Incidence of Nausea

\begin{tabular}{|c|c|c|c|c|}
\hline \multirow{2}{*}{ Group } & \multicolumn{4}{|c|}{ No. of Cases with Retching at } \\
\cline { 2 - 5 } & $\begin{array}{c}\mathbf{0 - 4} \\
\text { hours }\end{array}$ & $\begin{array}{c}\mathbf{4 - 8} \\
\text { hours }\end{array}$ & $\begin{array}{c}\mathbf{8 - 1 2} \\
\text { hours }\end{array}$ & $\begin{array}{c}\mathbf{1 2 - 2 4} \\
\text { hours }\end{array}$ \\
\hline Group 0 & 3 & 1 & 1 & 1 \\
\hline Group P & 1 & 0 & 0 & 0 \\
\hline 'p' & 0.311 & 0.5 & 0.5 & 0.5 \\
\hline \multicolumn{5}{|c|}{ Table B2: Incidence of Retching } \\
\hline
\end{tabular}

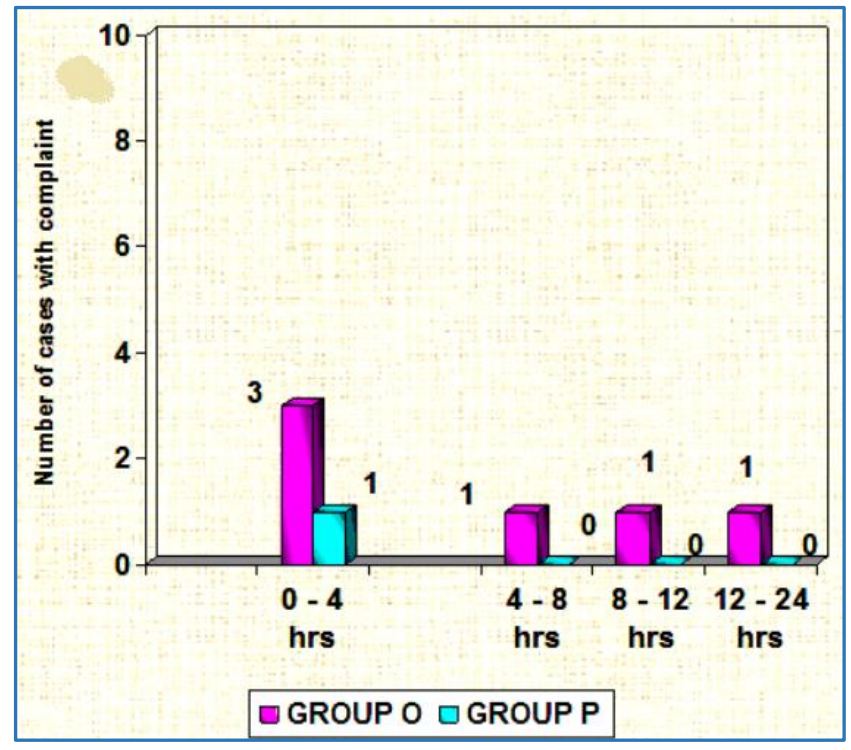

Fig. B2: Incidence of Retching

\begin{tabular}{|c|c|c|c|c|}
\hline \multirow{2}{*}{ Group } & \multicolumn{4}{|c|}{ No. of Cases with Vomiting } \\
\cline { 2 - 5 } & $\mathbf{0 - 4}$ hours & $\begin{array}{c}\mathbf{4 - 8} \\
\text { hours }\end{array}$ & $\begin{array}{c}\mathbf{8 - 1 2} \\
\text { hours }\end{array}$ & $\begin{array}{c}\mathbf{1 2 - 2 4} \\
\text { hours }\end{array}$ \\
\hline Group O & 8 & 4 & 9 & 8 \\
\hline Group P & 1 & 2 & 1 & 1 \\
\hline 'p' & $\begin{array}{c}0.0178 \\
\text { Significant }\end{array}$ & 0.3418 & $\begin{array}{c}0.0238 \\
\text { Significant }\end{array}$ & $\begin{array}{c}0.0178 \\
\text { Significant }\end{array}$ \\
\hline \multicolumn{5}{|c|}{ Table B3: Incidence of Vomiting } \\
\hline
\end{tabular}

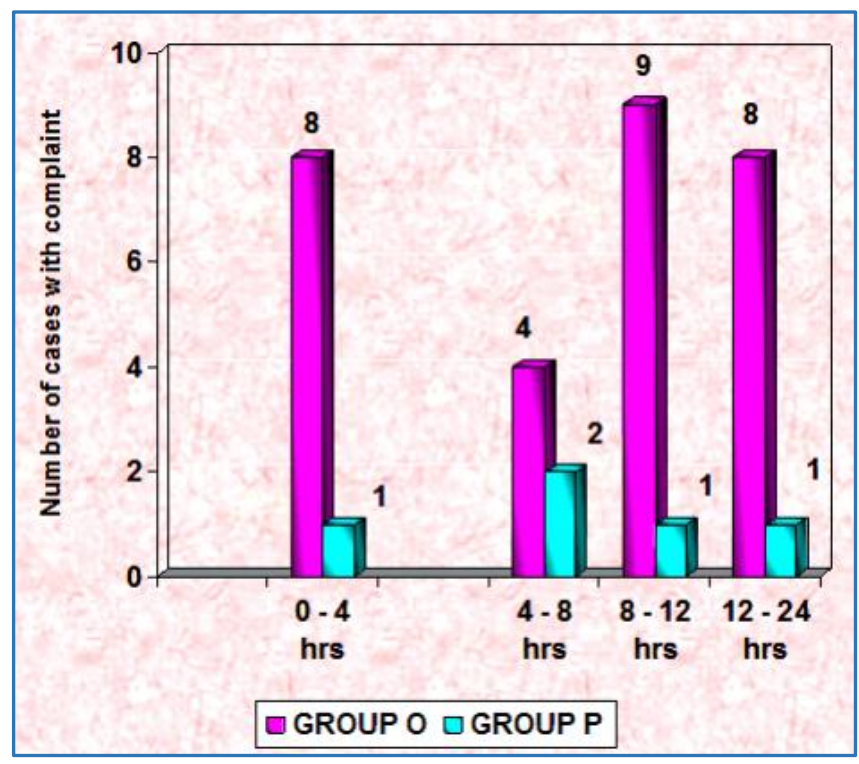

Fig. B3: Incidence of Vomiting

\begin{tabular}{|c|c|c|c|c|}
\hline \multirow{2}{*}{ Group } & \multicolumn{4}{|c|}{ No. of Cases requiring Rescue Antiemetic } \\
\cline { 2 - 5 } & $\begin{array}{c}\mathbf{0 - 4} \\
\text { hours }\end{array}$ & $\begin{array}{c}\mathbf{4 - 8} \\
\text { hours }\end{array}$ & $\begin{array}{c}\mathbf{8 - 1 2} \\
\text { hours }\end{array}$ & $\begin{array}{c}\mathbf{1 2 - 2 4} \\
\text { hours }\end{array}$ \\
\hline Group 0 & 4 & 2 & 3 & 4 \\
\hline Group P & 1 & 1 & 0 & 1 \\
\hline 'p' & 0.185 & 0.5 & 0.1235 & 0.185 \\
\hline \multicolumn{5}{|c|}{ Table B4: Rescue Antiemetic } \\
\hline
\end{tabular}




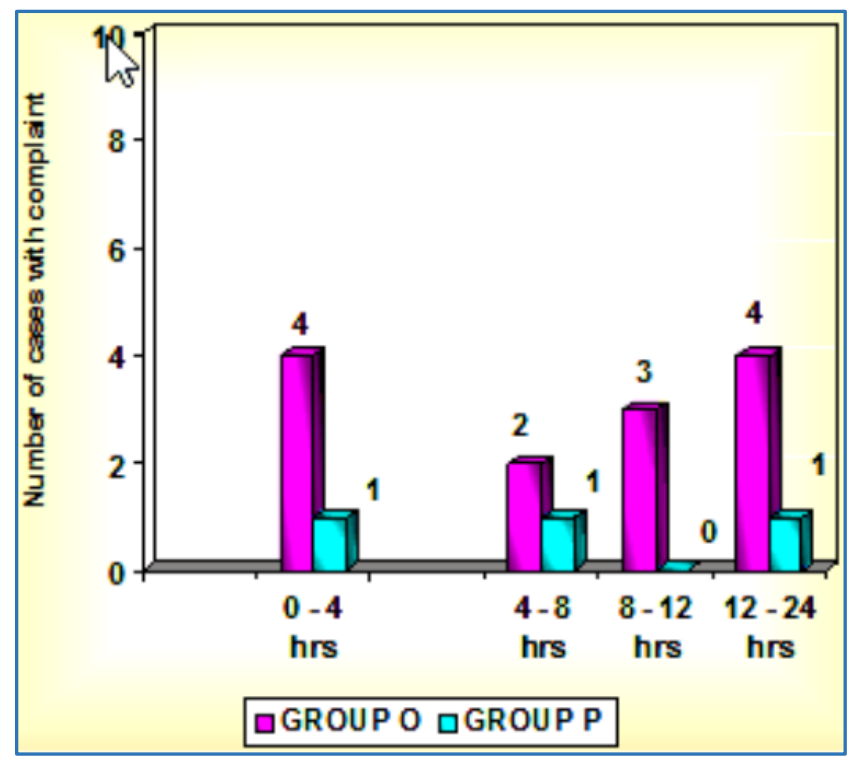

Fig. B4: Rescue Antiemetic

\begin{tabular}{|c|c|c|c|c|c|c|c|c|c|}
\hline \multirow{4}{*}{ Complication } & \multicolumn{8}{|c|}{ Overall Incidence of Complications in } & \multirow{4}{*}{ 'p' value } \\
\hline & \multicolumn{4}{|c|}{ Group 0} & \multicolumn{4}{|c|}{ Group P } & \\
\hline & \multicolumn{2}{|c|}{ Present } & \multicolumn{2}{|c|}{ Absent } & \multicolumn{2}{|c|}{ Present } & \multicolumn{2}{|c|}{ Absent } & \\
\hline & No. & $\%$ & No. & $\%$ & No. & $\%$ & No. & $\%$ & \\
\hline Nausea & 33 & 26.6 & 91 & 73.4 & 11 & 8.9 & 113 & 91.1 & 0.0005 Significant \\
\hline Retching & 6 & 4.8 & 118 & 95.2 & 1 & 0.8 & 123 & 99.2 & 0.0598 Not significant \\
\hline Vomiting & 37 & 21.8 & 97 & 78.2 & 5 & 4.0 & 119 & 96 & 0.0001 Significant \\
\hline Rescue antiemetic & 13 & 10.5 & 111 & 89.5 & 3 & 2.4 & 121 & 97.6 & 0.02 Significant \\
\hline Any one complication & $42^{*}$ & 33.9 & 82 & 71.9 & $17^{*}$ & 13.7 & 107 & 86.3 & 0.0003 Significant \\
\hline & & B5: & & $n c$ & & $t i$ & $p$ & ons & \\
\hline
\end{tabular}

*some cases had more than one complication

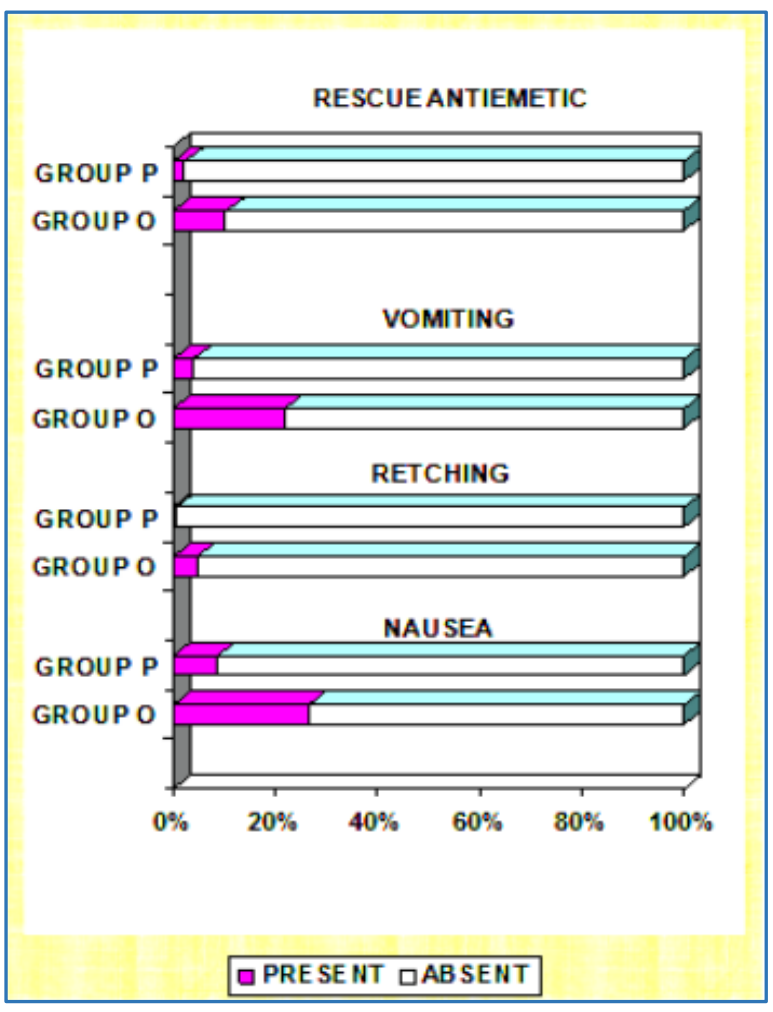

Fig. B5a: Overall Incidence of Postoperative Complications

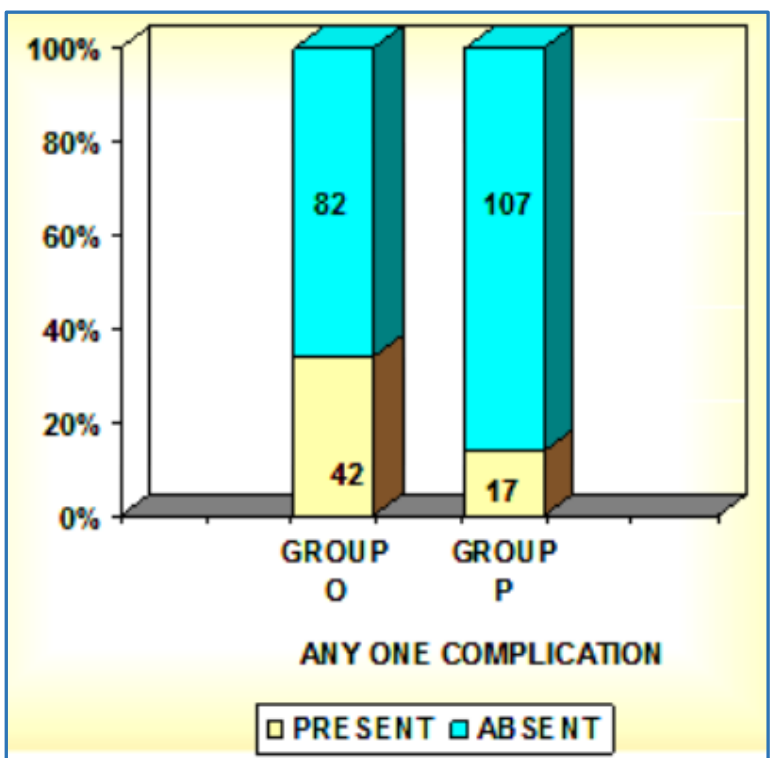

Fig. B5b: Overall Incidence of Any One Complication

\begin{tabular}{|c|c|c|}
\hline Group & $\begin{array}{c}\text { No. of Cases with } \\
\text { Headache }\end{array}$ & $\begin{array}{c}\text { No. of Cases with } \\
\text { Dizziness }\end{array}$ \\
\hline Group O & 12 & 6 \\
\hline Group P & 3 & 2 \\
\hline 'p' & $\begin{array}{c}0.0331 \\
\text { (Significant) }\end{array}$ & $\begin{array}{c}0.1405 \\
\text { (Not Significant) }\end{array}$ \\
\hline \multicolumn{2}{|c|}{ Table B6: Incidence of Side Effects } \\
\hline
\end{tabular}




\section{DISCUSSION}

5-HT3 receptors antagonists are routinely used nowadays to prevent postoperative nausea and vomiting in the patients undergoing abdominal surgeries under general anaesthesia. Currently available 5-HT3 antagonists include Ondansetron, Granisetron, Dolasetron, Tropisetron and Palonosetron. ${ }^{5}$ FDA has approved the use of Palonosetron for prophylaxis of PONV in 2008 and is now available in India. All 5-HT3 receptor antagonists have the same basic double nitrogen ring backbone for their chemical structure. This may be the clinical site of action of the 5-HT3 receptor antagonists. Half-life of Ondansetron is 3.5 to $5.5 \mathrm{hrs}$. and that of Palonosetron is 40 hrs. ${ }^{6}$ This confers Palonosetron prolonged duration of action and less frequent dosing as compared to Ondansetron.

A randomized study was done by Paventi $S$ et al in the year 2001 to compare the efficacy of Ondansetron $4 \mathrm{mg}$ and Ondansetron $8 \mathrm{mg}$ for the prevention of Postoperative Nausea and Vomiting (PONV) after laparoscopic cholecystectomy in 60 patients. The study showed that during the first $6 \mathrm{hrs}$. postoperatively, the incidence of PONV with Ondansetron 4 $\mathrm{mg}$ and $8 \mathrm{mg}$ were similar. After $6 \mathrm{hrs}$. the incidence of PONV increased significantly in patients who had received Ondansetron $4 \mathrm{mg}(\mathrm{p}=0.01)$ and was greater than that in patients who had received Ondansetron $8 \mathrm{mg}(\mathrm{p}=0.001)$. The study concluded that single-dose Ondansetron $8 \mathrm{mg}$ is more effective than Ondansetron $4 \mathrm{mg}$ in the prevention of PONV after laparoscopic cholecystectomy. So Ondansetron $8 \mathrm{mg}$ was considered as an optimal dose for the study. ${ }^{7}$

Study to optimise the dose of Palonosetron was done in 2008 by Kovac AL et al. In the study, Palonosetron in dose of $0.025 \mathrm{mg}, 0.05 \mathrm{mg}$ and $0.075 \mathrm{mg}$ was used and were compared in 546 patients undergoing laparoscopic surgery. Only the highest $0.075 \mathrm{mg}$ dose showed a significantly improved rate of complete response compared with placebo in the 0-6 hrs., 0$24 \mathrm{hrs}$. and $0-72 \mathrm{hrs}$. periods ( $49 \%$ vs. $37 \%$; $43 \%$ vs. $26 \%$; $39 \%$ vs. $24 \%$ for each periods respectively, $\mathrm{p}<0.05$ ). The Palonosetron $0.075 \mathrm{mg}$ dose was statistically superior to placebo for all end points during the first $24 \mathrm{hrs}$. including CR (complete remission), emesis, nausea rates and reduction in nausea severity. Also Palonosetron $0.075 \mathrm{mg}$ was associated with significantly longer median time to first emesis and a significantly longer time to treatment failure. Based on the above study, minimum effective dose of Palonosetron in the setting of PONV is $0.075 \mathrm{mg} .{ }^{8}$

Present study was done to compare the efficacy of Palonosetron $0.075 \mathrm{mg}$ and Ondansetron $8 \mathrm{mg}$ for prevention of PONV administered at the time of induction of anaesthesia in the patients undergoing laparoscopic abdominal surgeries under general anaesthesia.

In our study both the groups were comparable with respect to age, sex, body weight and duration of surgical procedure (Table A). The observations were statistically not significant with $\mathrm{p}>0.05$.

In our study incidence of nausea during 0-4 hours, 4-8 hours interval was $16 \%, 14 \%$ in group 0 and $14 \%, 2 \%$ in group $\mathrm{P}$ as shown in Table B1 and Figure B1 which was clinically and statistically significant with $\mathrm{p}$ value of 0.0226 and 0.0045 during respective intervals. Overall incidence of nausea in our study during first 24 hours post-operative period was 33\% and $11 \%$ in group 0 and group $P$ respectively as shown in Table B5 and Figure B5 with p value of 0.0005 , which was clinically and statistically significant and comparable to study conducted by Park SK, Cho EJ (2011). ${ }^{9}$ and Moon YE, Joo J, Kim JE, Lee Y (2012). ${ }^{10}$ in which severity of nausea was significantly lower in the Palonosetron group than in the Ondansetron group during 2-24 hours. In Bajwa SS (2012). ${ }^{11}$ study the incidence of nausea was $20 \%$ and $6.67 \%$ in Ondansetron and Palonosetron group respectively, which was statistically significant $(\mathrm{p}<0.05)$ and comparable with our study. The study confirms the finding that Palonosetron at a dose of $0.075 \mathrm{mg}$ improves the control of nausea and vomiting, which is even seen to extend over second and third day, an effect that may be most marked after major operations requiring inpatient stay.

In our study the incidence of vomiting during 0-4 hours, 8-12 hours, 12-24 hours intervals as shown in Table B3, Figure B3 were statistically significant. Overall incidence of vomiting in our study was $21.8 \%$ in Group 0 and $4 \%$ in Group P with p value of 0.0001 as shown in Table B5, Figure B5 which was statistically significant and comparable to results concluded by Bajwa SS (2011). ${ }^{11}$ Park SK, Cho EJ (2011). ${ }^{9}$ and Moon YE, Joo J, Kim JE, Lee Y (2012). ${ }^{10}$ In Bajwa SS (2011). ${ }^{11}$ study $13.33 \%$ of Ondansetron group and $3.33 \%$ of Palonosetron group had vomiting which was significant $(\mathrm{p}<0.05)$ and comparable to our study. In our study, it was noticed that incidence of vomiting was high in the Ondansetron group mainly between $8-12$ hours and 12-24 hours interval. This is mainly due to its relative short life of 3.5 to $5 \mathrm{hrs}$. In the patients who received Palonosetron, the incidence of vomiting was less because it has longer duration of action of $40 \mathrm{hrs}$.

In our study, overall use of rescue antiemetic was $10.5 \%$ in group 0 and $2.4 \%$ in group $P$ with p value of 0.02 which was statistically significant as shown in Table B5 and Figure B5. This was comparable with the study conducted by Moon YE, Joo J, Kim JE, Lee Y (2012). ${ }^{10}$ in which the difference in use of rescue antiemetic at $2-24$ hrs. was $10 \%$ with Palonosetron group compared with $28 \%$ with Ondansetron group with $\mathrm{p}$ value of 0.02 , which was statistically significant and Bajwa SS (2011). ${ }^{11}$ study in which the mean rescue dose of antiemetic was significantly higher $(10.6 \mathrm{mg})$ in the Ondansetron group as compared to Palonosetron group $(6.4 \mathrm{mg})(\mathrm{P}=0.036)$. None of the patient in our study had more than two episodes of vomiting, administration of rescue antiemetic metoclopramide $10 \mathrm{mg}$ IV was effective in preventing further PONV and hence dexamethasone $4 \mathrm{mg}$ IV was not used.

In our study, the incidence of PONV was $33.9 \%$ in Ondansetron group and $13.7 \%$ in Palonosetron group with $\mathrm{p}$ value of 0.0003 as shown in Table B5 and Figure B5b, which was statistically significant and comparable to results concluded by Park SK, Cho EJ (2011). ${ }^{9}$ in which incidence of PONV (42.2\% vs. 66.7\%) was significantly lower in the Palonosetron group than in the Ondansetron group during the overall 0-24 hr. time interval $(\mathrm{p}<0.05)$ and Moon YE, Joo J, Kim JE, Lee Y (2012).10 in which incidence of PONV during the 24 hrs. postoperative period was lower in the Palonosetron group than in the Ondansetron group ( $42 \%$ vs. $62 \%, \mathrm{p}=0.045)$. Here, even though some patient had more than one symptom we considered it as one case of PONV.

Both Palonosetron and Ondansetron has non-serious adverse effects like short duration headache, constipation, dizziness, diarrhoea and prolongation of QTc interval. In our study, incidence of headache was $9.7 \%$ in Ondansetron group and $2.4 \%$ in Palonosetron group which was found to be statistically significant $(\mathrm{p}=0.0331)$ as shown in Table B6 and comparable to study conducted by Bazwa SS et al (2011).11, in 
which $20 \%$ of the patients in Ondansetron group experienced significant post-op headache as compared to $6.67 \%$ in Palonosetron group. Unlikely, there was no significant difference in side effects observed in Park SK, Cho EJ (2011). ${ }^{9}$ and Moon YE, Joo J, Kim JE, Lee Y (2012). ${ }^{10}$ studies. Headache was managed by administration of single dose of paracetamol $10 \mathrm{mg} / \mathrm{kg}$ IV in our study. Hence, Palonosetron has favourable side effect profile compared to Ondansetron.

\section{CONCLUSION}

Incidence of PONV and use of rescue anti-emetics is less in patients who had received IV Palonosetron in comparison to those who had received IV Ondansetron in patients undergoing laparoscopic abdominal surgeries under GA. From the study, we conclude that Palonosetron at a dose of $0.075 \mathrm{mg}$ is safe, well tolerated and proved more effective than Ondansetron $8 \mathrm{mg}$ in prevention of PONV.

\section{REFERENCES}

1. Madej T, Simpsom K. Comparison of the use of domperidone, droperidol and metoclopramide in the prevention of nausea and vomiting following gynaecological surgery. Br J Anaesth 1986;58(8):879-83.

2. Jellish WS, Leonetti JP, Sawicki $K$, et al. Morphine/Ondansetron PCA for postoperative pain, nausea and vomiting after skull base surgery. Otolaryngol Head Neck Surg 2006;135(2):175-81.

3. Rojas C, Stathis M, Thomas AG, et al. Palonosetron exhibits unique molecular interactions with the $5-\mathrm{HT}_{3}$ receptor. Anesth Analg 2008;107(2):469-78.

4. Gralla R, Lichinitser M, Vander Vegt S, et al. Palonosetron improves prevention of chemotherapy induced nausea and vomiting following moderately emetogenic chemotherapy: results of a double-blind randomized phase 3 trial comparing single doses of palonosetron with ondansetron. Ann Oncol 2003;14(10):1570-7.
5. Yoshitaka F, Hiroyoshi T, Hideori T. Optimal antiemetic dose of granisetron for prevention of postoperative nausea and vomiting. Can J Anaesth 1994;41:94-7.

6. Muchatuta NA, Paech MJ. Management of postoperative nausea \& vomiting, focus on palonosetron. Therapeutics and Clinical Risk Management 2009;5:21-34.

7. Paventi S, Santevecchi A, Ranieri R. Efficacy of a single-dose ondansetron for preventing postoperative nausea and vomiting after laparoscopic cholecystectomy with sevoflurane and remifentanil infusion anaesthesia. European Review for Medical and Pharmacological Sciences 2001;5(2):59-63.

8. Kovac AL, Eberhart L, Kotarski J, et al. A randomized, double blind study to evaluate the efficacy and safety of three different doses of palonosetron versus placebo in preventing postoperative nausea and vomiting over a 72 hrs period. Anaesth Analg 2008;107(2):439-44.

9. Park SK, Cho EJ. A randomized, double blind trial of palonosetron compared with ondansetron in preventing postoperative nausea and vomiting after gynaecological laparoscopic surgery. J Int Med Res 2011;39(2):399-407.

10. Moon YE, Joo J, Kim JE, et al. Anti-emetic effect of ondansetron and palonosetron in thyroidectomy: a prospective, randomized, double-blind study. $\mathrm{Br} \mathrm{J}$ Anaesth 2012;108(3):417-22.

11. Bajwa SS, Bajwa SK, Kaur J, et al. Palonosetron: a novel approach to control postoperative nausea and vomiting in day care surgery. Saudi J Anaesth 2011;5(1):19-24. 